\title{
Location Analysis and Strontium-90 Concentrations in Deer Antlers on the Hanford Site
}
B. L. Tiller
L. E. Eberhardt
T. M. Poston

May 1995

Prepared for the U.S. Department of Energy under Contract DE-AC06-76RLO 1830

Pacific Northwest Laboratory Operated for the U.S. Department of Energy by Battelle Memorial Institute 


\title{
DISCLAIMER
}

This report was prepared as an account of work sponsored by an agency of the United States Government. Neither the United States Government nor any agency thereof, nor Battelle Memorial Institute, nor any of their employees, makes any warranty, express or implied, or assumes any legal liability or responsibility for the accuracy, completeness, or usefulness of any information, apparatus, product, or process disclosed, or represents that its use would not infringe privately owned rights. Reference herein to àny specific commercial product, process, or service by trade name, trademark, manufacturer, or otherwise does not necessarily constitute or imply its endorsement, recommendation, or favoring by the United States Government or any agency thereof, or Battelle Memorial Institute. The views and opinions of authors expressed herein do not necessarily state or reflect those of the United States Government or any agency thereof.

\author{
PACIFIC NORTHWEST LABORATORY \\ operated by \\ BATTELLE MEMORIAL INSTITUTE \\ for the \\ UNITED STATES DEPARTMENT OF ENERGY \\ under Contract DE-ACO6-76RLO 1830
}

Printed in the United States of America

Available to DOE and DOE contractors from the

Office of Scientific and Technical Information, P.O. Box 62, Oak Ridge, TN 37831; prices available from (615) $576-8401$.

\begin{abstract}
Available to the public from the National Technical Information Service,
U.S. Department of Commerce, 5285 Port Royal Rd., Springfield, VA 22161
\end{abstract}




\section{DISCLAIMER}

Portions of this document may be illegible in electronic image products. Images are produced from the best available original document. 


\title{
DISCLAIMER
}

This report was prepared as an account of work sponsored by an agency of the United States Government. Neither the United States Government nor any agency thereof, nor any of their employees, makes any warranty, express or implied, or assumes any legal liability or responsibility for the accuracy, completeness, or usefulness of any information, apparatus, product, or process disclosed, or represents that its use would not infringe privately owned rights. Reference herein to any specific commercial product, process, or service by trade name, trademark, manufacturer, or otherwise does not necessarily constitute or imply its endorsement, recommendation, or favoring by the United States Government or any agency thereof. The views and opinions of authors expressed herein do not necessarily state or reflect those of the United States Government or any agency thereof.

\section{Location Analysis and Strontium-90 Concentrations in Deer Antlers on the Hanford Site}

\author{
B. L. Tiller \\ L. E. Eberhardt \\ T. M. Poston
}

May 1995

Prepared for

the U.S. Department of Energy

under Contract DE-AC06-76RLO 1830

Pacific Northwest Laboratory

Richland, Washington 99352

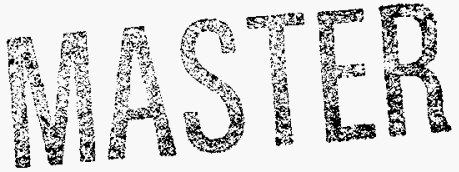





\section{Summary}

This study was initiated to evaluate the use of deer antlers as indicators of animal exposure to ${ }^{90} \mathrm{Sr}$ on the Hanford Site in southcentral Washington. Levels of strontium-90 ( ${ }^{\infty} \mathrm{Sr}$ ) were examined in antlers of Rocky Mountain mule deer (Odocoileus hemionus hemionus) residing near previously active reactor sites and from locations at approximately 10 to 30 kilometers away from the reactor sites. In addition, samples were also collected from a remote area in central Oregon unassociated with plutonium production and were used as a reference standard.

From 1991 to 1994,38 deer antler samples were collected and analyzed for ${ }^{90} \mathrm{Sr}$ contamination. Antlers were collected from 18 bucks that were tagged with radio transmitters to monitor their movements. A significant difference $(\mathrm{P}<0.001)$ in ${ }^{90} \mathrm{Sr}$ concentrations in antlers was observed between the two Hanford Site areas (reactor areas and the area unassociated with reactors). Examining subsequent movements of 18 bucks and several does confirmed that little to no intermixing existed between the two study sites. Reference antlers collected in central Oregon had nearly five times the ${ }^{90} \mathrm{Sr}$ concentration found in Hanford Site mule deer antlers and is attributed to world wide fallout levels found there. Soil samples were also collected from these three areas and analyzed for ${ }^{90} \mathrm{Sr}$. Analysis of Variance demonstrated a significant difference between Hanford and Oregon soils but no soil differences were found between the two Hanford Site study areas. Natural vegetation samples were collected within the two Hanford Site study areas and analysis demonstrated no significant difference in ${ }^{90} \mathrm{Sr}$ between them. Regression analysis of the Hanford and Oregon data demonstrated a significant correlation between soil and antler ${ }^{90} \mathrm{Sr}$ concentrations.

Movement analysis suggest that the Columbia River does not restrict deer movement from on and off the Hanford Site. Average home range estimates for several deer ranged from $15.4 \mathrm{~km}^{2}$ by the $95 \%$ minimum convex polygon method to $33.6 \mathrm{~km}^{2}$-by the $95 \%$ bivariate ellipse method, which supports previous home range estimates for mule deer residing in a shrub-steppe ecosystem. Based on data gathered from 1991 to 1994 , an average of $11 \%$ (range $0 \%$ to $37 \%$ at the $95 \%$ confidence interval) of the male deer residing along the Columbia River may be harvested in any one year. A lower average harvest rate (legal or illegal) of female deer was determined to be 5\% (range $0 \%$ to $21 \%$ at the $95 \%$ confidence level) and is consistent with Eberhardt et al. 1982 findings. A population estimate is needed to determine the actual number of deer harvested in any one year.

Antlers of mule deer can be useful for detecting localized contamination of bone-seeking contaminants like ${ }^{90} \mathrm{Sr}$ or other heavy metals. Thus, collecting shed antlers can be used as a nondestructive tool for contaminant monitoring. 


\section{Acknowledgments}

The authors wish to thank W. H. Rickard, L. L. Cadwell, and R. G. Schreckhise for their insight and assistance in the study design development. The authors further appreciate all of the many SERS, SRAP, and AWU-NW students for their invaluable assistance in field data collections and deer captures. R. K. Zufelt provided GPS/GIS interface and graphical illustrations of this study. Editing and report production were provided by G. P. O'Connor and the Sigma V Communications Support

Team. The authors would also like to thank the PNL Flight Aviation Safety Committee for assisting in aircraft operations setup and ensuring that this work could be performed under current DOE aviation safety guidelines. 


\section{Contents}

Summary $\ldots \ldots \ldots \ldots \ldots \ldots \ldots \ldots \ldots \ldots \ldots \ldots \ldots \ldots \ldots \ldots$ iii

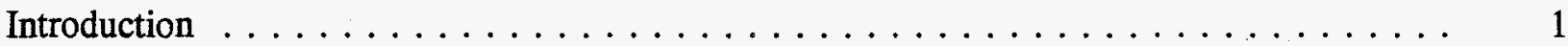

Study Area $\ldots \ldots \ldots \ldots \ldots \ldots \ldots \ldots \ldots \ldots \ldots \ldots \ldots$

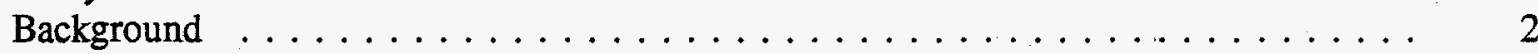

Preview of Report $\ldots \ldots \ldots \ldots \ldots \ldots \ldots \ldots \ldots \ldots \ldots \ldots$

Methods $\ldots \ldots \ldots \ldots \ldots \ldots \ldots \ldots \ldots \ldots \ldots \ldots \ldots \ldots \ldots \ldots \ldots \ldots \ldots$

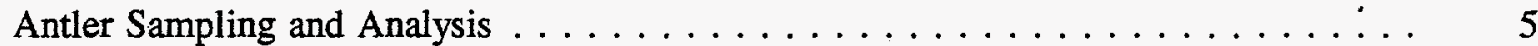

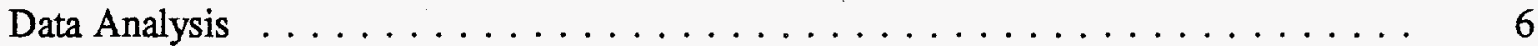

Evaluation of Onsite Soil and Vegetation Strontium-90

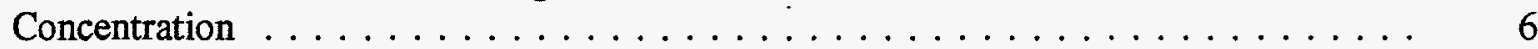

Results and Discussion $\ldots \ldots \ldots \ldots \ldots \ldots \ldots \ldots \ldots$

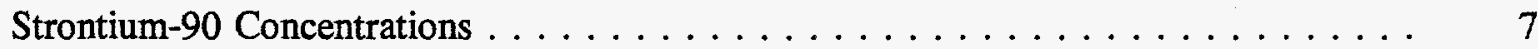

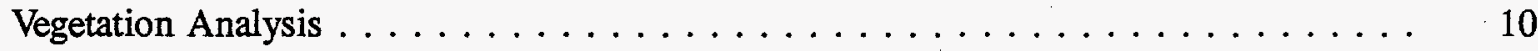

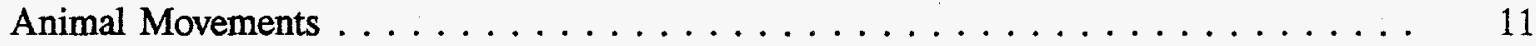

Offsite Movements and Harvest Potential $\ldots \ldots \ldots \ldots \ldots \ldots$

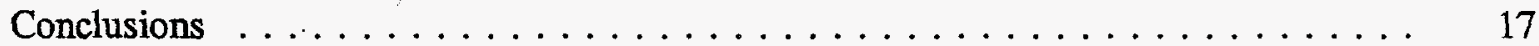

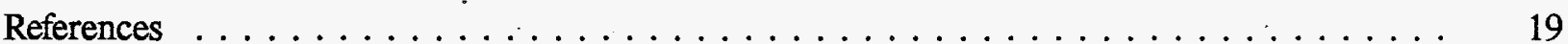

Appendix A - Raw Data and Statistical Results $\ldots \ldots \ldots \ldots \ldots \ldots \ldots$

Appendix B - Home Range Results $\ldots \ldots \ldots \ldots \ldots \ldots \ldots \ldots \ldots \ldots \ldots$. . . . . . . . 


\section{Figures}

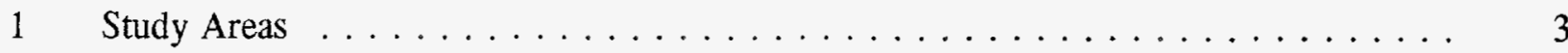

2 Mean \pm 2 Standard Error Strontium-90 Concentrations in Antlers $\ldots \ldots \ldots$

3 Soil and Vegetation Sampling Locations included in Hanford

Analysis . . . . . . . . . . . . . . . . . . . . . . . . 9

4 Regression Analysis of Antler Versus Soil Data . . . . . . . . . . . . . 10

5 Deer Locations Relative to Capture Sites $1991-1992 \ldots \ldots \ldots \ldots$

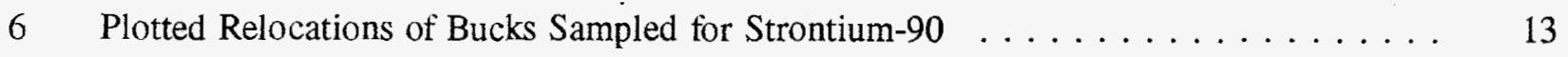

7 Home Ranges of Selected Bucks and Does on Hanford $\ldots \ldots \ldots \ldots$ 


\section{Tables}

1 ANOVA of Log-Transformed Strontium-90 in Selected Soil Samples Corresponding to North and South Deer Home Ranges . . . . . . . . . . . . . . . . . . . . . 10

2 ANOVA of Log-Transformed Strontium-90 in Selected Vegetation Samples Corresponding to North and South Deer Home Ranges . . . . . . . . . . . . . . . 11

3 Distribution of Locations from the Columbia River $\ldots \ldots \ldots \ldots \ldots$ 


\section{Introduction}

The Rocky Mountain mule deer (Odocoileus hemionus hemionus) is an important component of the ecosystem and a highly valued species for both aesthetics and hunting. Also, because mule deer are often hunted and eaten, they potentially can contribute to the annual radiation dose received by members of the public (Soldat et al. 1990; McClelland et al. 1993). On the Hanford Site in southcentral Washington, the species is also of interest to contaminant monitoring programs because deer can provide useful information that can be used in environmental clean up efforts (Eberhardt and Cadwell 1983). The mule deer study described here was conducted as part of the Hanford Site's Wildlife Resources Monitoring Project (WRMP) and analytical support was provided by the Surface Environmental Surveillance Project. Pacific Northwest Laboratory (PNL) manages the project for the U.S. Department of Energy (DOE). The purposes of the WRMP are to monitor and report trends in wildlife populations, conduct surveys to identify, record, and map populations of threatened, endangered, and sensitive plant and animal species, and cooperate with Washington State and federal and private agencies to help ensure the protection afforded by law to native species and their habitats.

The primary objective of this study was to examine the levels of strontium-90 ( $\left.{ }^{90} \mathrm{Sr}\right)$ in deer antlers collected from near previously active reactor sites and distant from the reactor sites along that portion of the Columbia River which borders the Hanford Site. A second objective was to analyze the movements and home-ranges of mule deer residing within these areas and determine to what extent this information contributes to the observed ${ }^{90} \mathrm{Sr}$ concentrations. ${ }^{90} \mathrm{Sr}$ is a long-lived radionuclide (29.1 year half life) produced by fission in irradiated fuel in plutonium production reactors on the Hanford Site. It is also a major component of atmospheric fallout from weapons testing. Concentrations of radionuclides found in the developed environment onsite do not pose a health concern to humans or various wildlife routinely monitored (Woodruff and Hanf 1992). However, elevated levels of radionuclides in found biota may indicate routes of exposure requiring attention.

The utility of a nondestructive approach for collecting a relatively large number of deer tissue samples for radiological analysis was examined. The approach utilizes shed antlers which occurs annually for most all male deer. In this way antlers can be collected and analyzed for contamination without sacrificing the animal and with minimal sample preparation efforts. Although not yet substantiated, it has been postulated that the concentration of ${ }^{90} \mathrm{Sr}$ in antlers is a reflection of environmental contamination within the animals area of use (Zaleha and Kovach 1985). Consequently, information about animal movements and home-range sizes would contribute significantly to the evaluation of using deer antler tissue for environmental monitoring. Previous mule deer studies conducted on the Hanford Site indicate that concentrations of radionuclides in deer tissue are similar to concentrations expected from worldwide fallout (Woodruff and Hanf 1992). However, small sample sizes coupled with the relatively low concentrations found in animals today makes it difficult to interpret the radionuclide results.

\section{Study Area}

The study was conducted along that portion of the Hanford Site that borders the Columbia River. The Columbia River Plain, a broad, low-elevation valley located in southcentral Washington, has been 
occupied by settlers and used extensively for livestock grazing since the 1850 s, and later, for cultivation agriculture and urbanization (Chatters 1989). The Hanford Site was established in 1943 as a national security area and has been closed to public access since that date. The area, in general, is characterized by steppe vegetation, sagebrush (Artemisia tridentata)/Sandberg's bluegrass (Poa sandbergii) (Downs et al. 1993; Daubenmire 1970), with approximately $16 \mathrm{~cm}$ of annual precipitation (Hoitink and Burk 1994). The climate consists of hot dry summers and relatively cool winters when the bulk of annual precipitation occurs.

Deer were studied throughout approximately $80 \mathrm{~km}^{2}$ of land bordering the Columbia River in Benton and Grant counties (Figure 1). The study region can be divided into north and south areas. The southern area generally has been unaltered by Hanford-related activities and is characterized by sand dunes, old abandoned farm fields, and shrub-steppe habitat that was burned in 1985. Rabbitbrush (Chrynsothamnus spp.) and bitterbrush (Purshia tridentata) are dominant shrubs occupying the dune habitat (Downs et al. 1993). The northern area contains six inactive production reactor sites, old abandoned agriculture fields, and scattered patches of shrub-steppe habitat.

The Columbia River supports riparian habitat and riverine islands commonly used by resident mule deer. The shoreline vegetation along the Hanford Reach consists of a narrow zone of broad-leafed deciduous trees and shrubs intermingled with a variety of perennial grasses and forbs (Downs et al. 1993; Sackschewsky et al. 1992). The riparian zone tends to remain green throughout the hot dry summer months because its rooting zones are wetted by river water or shallow groundwater.

Background deer antler and soil samples were also obtained form the Silver Lake region of central Oregon for comparison to deer antler samples collected from the Hanford Site. The Silver Lake region was selected because it is relatively arid, consisting of shrub-steppe vegetation. The mean annual average precipitation of the area is about $25 \mathrm{~cm}$ (WIC 1974), and it has been used in previous studies on ${ }^{129} \mathrm{~T}$ in wildlife (Price et al. 1981).

\section{Background}

Strontium found in deer antler tissue comes from two distinct sources: A relatively small portion of ${ }^{90} \mathrm{Sr}$ comes from deposits already present in bone that are remobilized and laid down in antler tissue as it is growing. The primary source comes from uptake of ${ }^{90} \mathrm{Sr}$ found in forage, soil, and drinking water. A substantial portion of ingested ${ }^{90} \mathrm{Sr}$ is absorbed from the gastrointestinal tract, and the remainder is excreted in the feces. The absorbed portion is either deposited in the bone, distributed in an exchangeable pool comprised of the plasma, extracellular fluid, soft tissues, and bone surfaces, or removed from the body by urinary and fecal excretion (Schreckhise 1974; NCRP 1991). Consequently, the concentrations of ${ }^{90} \mathrm{Sr}$ found in antler tissue are not entirely representative of uptake occurring when the antlers are growing; however, the majority of. ${ }^{90} \mathrm{Sr}$ and $\mathrm{Ca}$ laid down during antler growth is most likely dietary, thus reflective of its surrounding environment. Research has demonstrated that strontium is retained less effectively than calcium in living organisms, however, it is generally accepted that ${ }^{90} \mathrm{Sr}$ is biologically analogous to calcium and is therefore concentrated in calcium rich tissue (NCRP 1991). The biological half life of ${ }^{90} \mathrm{Sr}$ in mammals ranges from 100 to 700 days (DiGregorio et al. 1977). Strontium and calcium plasma/bone turnover is reduced in older aged animals (Farris et al. 1967). 




Figure 1. Study Areas 
Antlers are "true bone" (Wallmo 1981), and therefore, may be a useful tissue for estimating ${ }^{90} \mathrm{Sr}$ burdens in animals. The usefulness of monitoring antlers taken from a wild mule deer population to determine the potential exposure of ${ }^{90} \mathrm{Sr}$ in the deers' foraging environment has not been previously investigated on the Hanford Site. However, Zaleha and Kovach (1985) found ${ }^{90} \mathrm{Sr}$ contents in whitetailed deer to be principally a function of ${ }^{90} \mathrm{Sr}$ contents in soil and water existing throughout the animals' home range. In this way, examining the ${ }^{90} \mathrm{Sr}$ concentrations in antlers may be a useful tool for identifying areas of localized contamination.

On the Hanford Site, muscle and liver samples are routinely taken from road-killed deer for radionuclide analysis. If road-killed deer are not sampled from near certain reactor sites during the calendar year, up to four deer are sacrificed and sampled (Woodruff and Hanf 1992). Usually, eight or nine deer per year are collected onsite and analyzed for selected radionuclides, including ${ }^{137} \mathrm{Cs},{ }^{60} \mathrm{Co}$, and ${ }^{90} \mathrm{Sr}$. The results indicate very low amounts of radionuclides are taken up by animals; however, the variability of these results and relatively low sample sizes make it difficult to examine for differences in contaminant uptake by deer residing in different locations throughout Hanford. Eberhardt et al.

(1982) conducted studies on radio transmitted deer in the central portion of Hanford that resided at different distances from a known contamination site. After examining the animals' movement patterns, the researchers sacrificed the animals' and determined that radionuclide concentrations in the muscle, liver, and bone tissue were significantly correlated with distance from the contamination site and time the animal spent near the contamination site. Movements to offsite areas by the study animals were minimal, however, very few animals were studied near the Columbia River where offsite movements would be more likely.

\section{Preview of Report}

This report describes methods used to capture mule deer, fit them with tags and radio transmitters, and collect antler tissue for ${ }^{90} \mathrm{Sr}$ analysis. It reports results and discusses ${ }^{90} \mathrm{Sr}$ concentrations in soil, vegetation, and deer antlers samples, and describes animal movements and harvest potential. Study conclusions are also provided. Appendix A includes raw data, relative frequency distributions of antler results, and statistical tests for ${ }^{90} \mathrm{Sr}$ differences within and between sites described in this study. Appendix B includes goodness-of-fit tests for underlying movement distribution assumptions and a comparison of results for home range estimate techniques. 


\section{Methods}

This research involved capturing mule deer, fitting them with tags and radio transmitters, and collecting antler tissue, soil, and vegetation for ${ }^{\circ 0} \mathrm{Sr}$ analysis, and systematically monitoring subsequent movements of animals tagged with radio transmitters. Data analysis involved determining home-range size and applying statistical tests to determine if differences were present in ${ }^{90} \mathrm{Sr}$ concentration of soil, vegetation, and antler tissue based on location and extent of animal movements.

Deer were mass captured in drive nets (Beasom et al. 1980) at several locations along the Hanford Reach of the Columbia River during February and March of 1991, 1992, and 1993. Deer were visually located from a helicopter and then driven into the nearby net line, which typically took the shape of an "L." In 1994, several deer were captured with a CODA net gun fired from a hovering helicopter and then slung in a cargo net for transport to a nearby staging area. For all deer captured, incisor 1 lengths were measured, age was estimated, general health was noted, an Advanced Telemetry Systems (ATS) solar-powered radio transmitter was fastened to the ear of the adult males, and when available antler samples were collected. An ATS radio collar was fastened around the neck of all adult females. An incisiform canine was removed from several males for age determination by cementum annuli analysis (Erickson and Seliger 1969; Low and Cowan 1963; Robinette et al. 1957).

Animals tracked by radiotelemetry were systematically located by aircraft and/or by ground observers weekly (weather conditions permitting) during daylight hours. A Telonics XA receiver and two H-element antennas were used to locate each animal. Location points were determined with a Garmin GPS-100. Accuracy of aerial relocations was found to be between 0 and $100 \mathrm{~m}$ from equipment sources and estimated between 0 and $300 \mathrm{~m}$ from observer sources. Location coordinates were plotted on the GRASS Geographical Information System (GIS) to examine the extent of intermixing among animals tagged with radio transmitters and groups of animals not tagged, and to graphically illustrate animal home range estimates.

\section{Antler Sampling and Analysis}

During each capture event, antler samples were collected from bucks by clipping a 3- to 5-cm portion from the tips of each point. This sampling design was used because Schultz (1964) and Zelah and Kovach (1985) found the highest ${ }^{90} \mathrm{Sr}$ concentrations to exist in the dense peripheral zone of the antlers, but found no significant difference among particular antler points. A stainless-steel cutting shear was used to snip the antlers. Antler samples were surveyed in the field with a beta-gamma handheld instrument but no detectable levels of beta or gamma emitting radionuclides were found.

Analysis of antler samples was performed under contract by International Technology Company (IT). Samples were ashed in a muffle furnace and then dissolved in nitric acid. The dissolved ash was scavenged with barium nitrate, and the strontium was precipitated as a carbonate. The strontium carbonate precipitate was transferred to a stainless-steel planchet and counted on a gas flow proportional counter. At least $10 \mathrm{~g}$ of tissue was needed to attain a detection limit of $0.01 \mathrm{pCi} / \mathrm{g}$ dry weight. 


\section{Data Analysis}

Home range size estimates of animals tracked by radio transmitter were computed using a P.C. computer program developed at the University of Idaho (Ackerman et al. 1990). Home ranges were obtained using three techniques: $100 \%$ and $95 \%$ minimum convex poiygons (Michener 1979; Bowen 1982; Bekoff and Mech 1984), 95\% bivariate normal and 95\% bivariate weighted ellipse (Samuel and Garton 1985), and 95\% harmonic mean utilization (Dixon and Chapman 1980). Minimum convex polygons are concentric convex polygons whose boundaries encompass a specified innermost percentage of all the observations. This technique is useful for examining areas used by an individual throughout the study period, but may not necessarily provide information on the area that could be potentially used. In addition, this method is limited to comparing animal home ranges when there are equal number of locations for each animal. The bivariate ellipse (non-circular) estimators are parametric and relatively robust to low sample sizes, however, these are only useful for animals with a bivariate movement distribution. The Harmonic Mean technique is a nonparametric method but generally, a large number of observations $(n>60)$ is needed for an accurate home range estimation. Animal locations were tested for fit of underlying distribution assumptions for the ellipse techniques (bivariate uniform, bivariate normality, and weighted bivariate normality) using the Cramer-von Mises goodness-of-fit test (Samuel and Garton 1985, White and Garrott 1990) (Appendix B).

All results were plotted on a relative frequency to examine the contaminant concentration distributions (Appendix A). The non-parametric statistical program, Multi-Response Permutation Procedure (MRPP) was chosen to test for significant differences in ${ }^{90} \mathrm{Sr}$ concentrations between locations onsite and offsite (Mielke 1991) (Appendix A).

\section{Evaluation of Onsite Soil and Vegetation Strontium-90 Concentration}

The Hanford Site Surface Surveillance data base was searched for measurements of ${ }^{90} \mathrm{Sr}$ in soil and vegetation samples for 1983 through 1993. Data bases were constructed from soil and vegetation samples based on sampling locations that fell within the areas used by deer in this study. These sample locations were grouped into two areas, north and south, for statistical analysis. The distribution of the data was evaluated, and it was determined that a log transformation best approximated a normal distribution. Analysis of Variance (ANOVA) was conducted on the log-transformed soil and vegetation data based on area. Additionally, the ${ }^{90} \mathrm{Sr}$ database collected during a surveillance of shoreline vegetation from 1990 through 1992 was evaluated to determine the potential significance of shoreline vegetation as a possible source of ${ }^{90} \mathrm{Sr}$ for mule deer. Shoreline vegetation that contained elevated concentrations of ${ }^{90} \mathrm{Sr}$ close to the $100-\mathrm{N}$ Area were removed in 1992. 


\section{Results and Discussion}

\section{Strontium-90 Concentrations}

A total of 38 deer antler samples were analyzed for ${ }^{90} \mathrm{Sr}$ concentrations. Mule deer on the Site were partitioned into two major groups associated with the northern and southern study areas. These herds may represent combinations of smaller but distinct subgroups whose home ranges overlap; however, additional and more extensive monitoring of individual movements would be necessary to make this determination. Fourteen (37\%) samples came from animals captured near the 100 area reactor sites, fourteen (37\%) were collected from animals captured near or south of the old Hanford Townsite, and ten (26\%) were collected from the reference site near Silver Lake, Oregon.

Strontium-90 concentrations found in antler samples collected from 17 animals that were tracked by radio transmitter and 10 other untagged animals residing within the two (north and south) areas were tested for differences using the non-parametric Exact Multi-Response Permutation Procedure (EMRPP) and Multi-Response Permutation Procedure (MRPP). A non-parametric statistical program was chosen because the northern area data were not normally distributed (Appendix A). Initially, samples collected from near $100-\mathrm{BC}, 100-\mathrm{K}$, and $100-\mathrm{N}$ were grouped as one area, as were those samples collected near 100-D, 100-H, and 100-F. Results were subjectively grouped this way because this represented a minimum sample size for area comparisons. No statistical difference in ${ }^{90} \mathrm{Sr}$ concentrations from samples collected throughout the 100 areas was observed. However, when all 100 Area samples were considered as one group, a significant $(p<0.001)$ difference between the north (100 areas) and the south (old Hanford Townsite Area) was determined. Average dry-weight antler concentrations near and far from the reactor sites were $0.41( \pm 0.06) 1 \mathrm{SE} \mathrm{pCi} / \mathrm{g}$ and 0.19 $( \pm 0.02) 1 \mathrm{SE} \mathrm{pCi} / \mathrm{g}$, respectively (Figure 2). Statistical results are shown in Appendix A.

Concentrations found in antlers collected from the reference site (Silver Lake, Oregon) were approximately five times higher than those found in antlers from near the reactor sites (Figure 2 and raw data in Appendix A). Price et al. (1981) considered central Oregon to be an adequate reference for levels of ${ }^{129} \mathrm{I}$ in deer because this area is similar to the Hanford climate and habitat. Animals residing near Silver Lake, Oregon, migrate from the high mountains in the summer to the shrub-steppe basins in the winter where their shed antlers are found. Six soil samples were collected from near Silver Lake, three in the valley and three in the nearby mountains. Results from soil samples collected in the lower elevation area do not compliment the relatively high values observed in antlers collected in that region. However, results from samples collected at an area higher in elevation compliment the relatively high values observed in antlers collected from that region. The median concentration of ${ }^{90} \mathrm{Sr}$ in the Silver Lake basin and mountain soil samples was $0.180 \mathrm{pCi} / \mathrm{g}$ (range 0.136 to $0.233 \mathrm{pCi} / \mathrm{g}$ ) and 0.653 (range 0.537 to 0.669 ), respectively. 


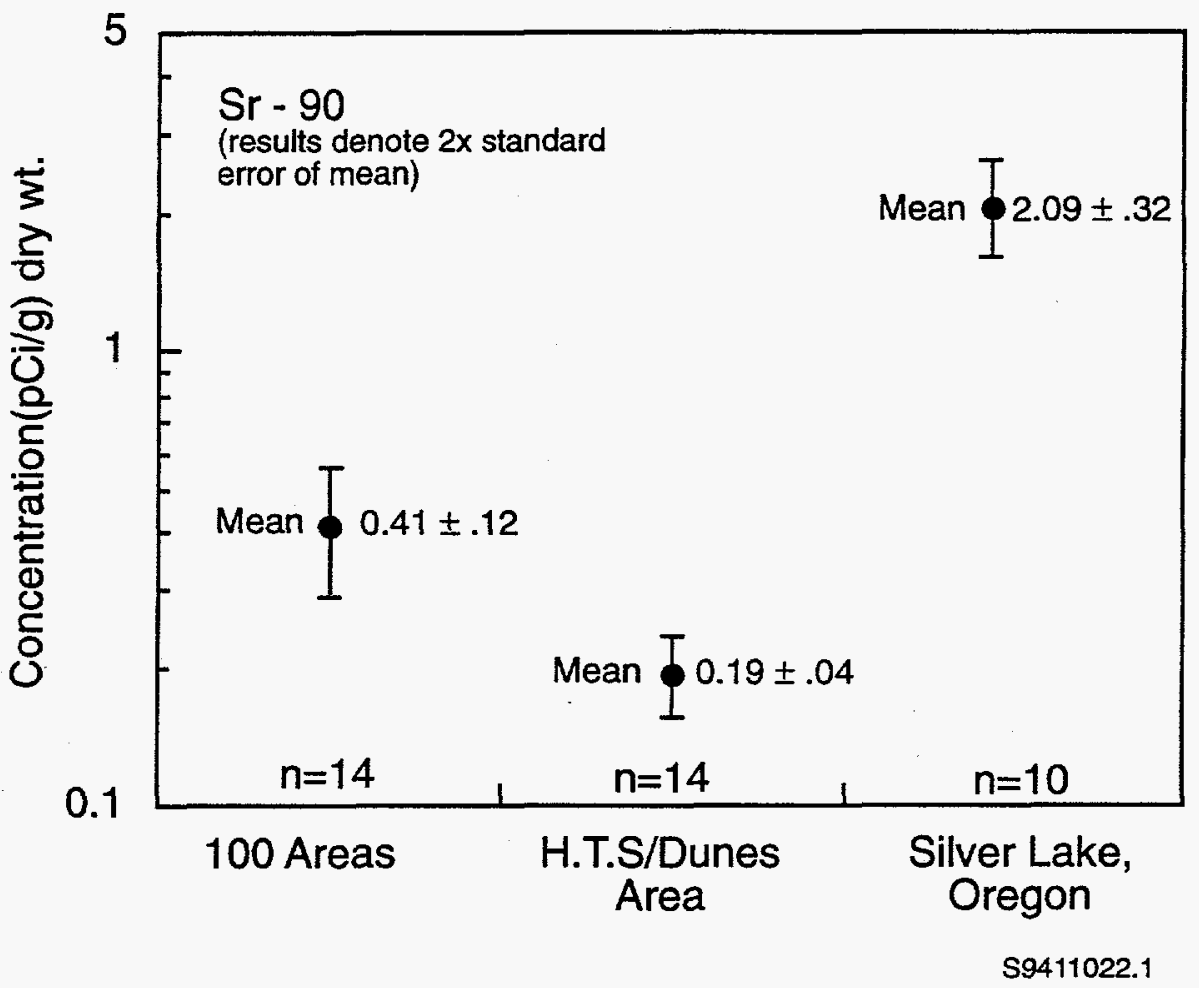

Figure 2. Mean \pm 1 Standard Error Strontium-90 Concentrations in Antlers

Soil data collected as part of the Hanford sitewide monitoring project was segregated into two groups, reflecting the north and south grouping of deer populations, and evaluated (Figure 3). The distribution of the soil data clearly indicated a $\log$-normal distribution, and the north and south area soil data were $\log$-transformed and subjected to ANOVA (Table 1). This analysis indicated no significant difference in groups $(P=0.551)$. The median concentration of ${ }^{90} \mathrm{Sr}$ in the combined study areas was $0.0206 \mathrm{pCi} / \mathrm{g}$ soil. The basin samples from Silver Lake are generally higher than the Hanford soil data summarized for this study, however, higher soil concentrations of ${ }^{90} \mathrm{Sr}$ were expected in the mountain soil samples due to higher amounts of precipitation there (Whicker 1965, Osburn 1967, Whicker 1983). Consequently, the elevated concentrations of ${ }^{90} \mathrm{Sr}$ in the Silver Lake deer antlers is not unexpected as there is an apparent higher background exposure level because of historic atmospheric fallout from weapons testing. A regression analysis between the soil and antler data from all three locations (Silver Lake, 100 North Areas, and the South Area) was significant $\left(p<0.001 ; R^{2}=0.700\right)$ to 0.699 (Figure 4). 


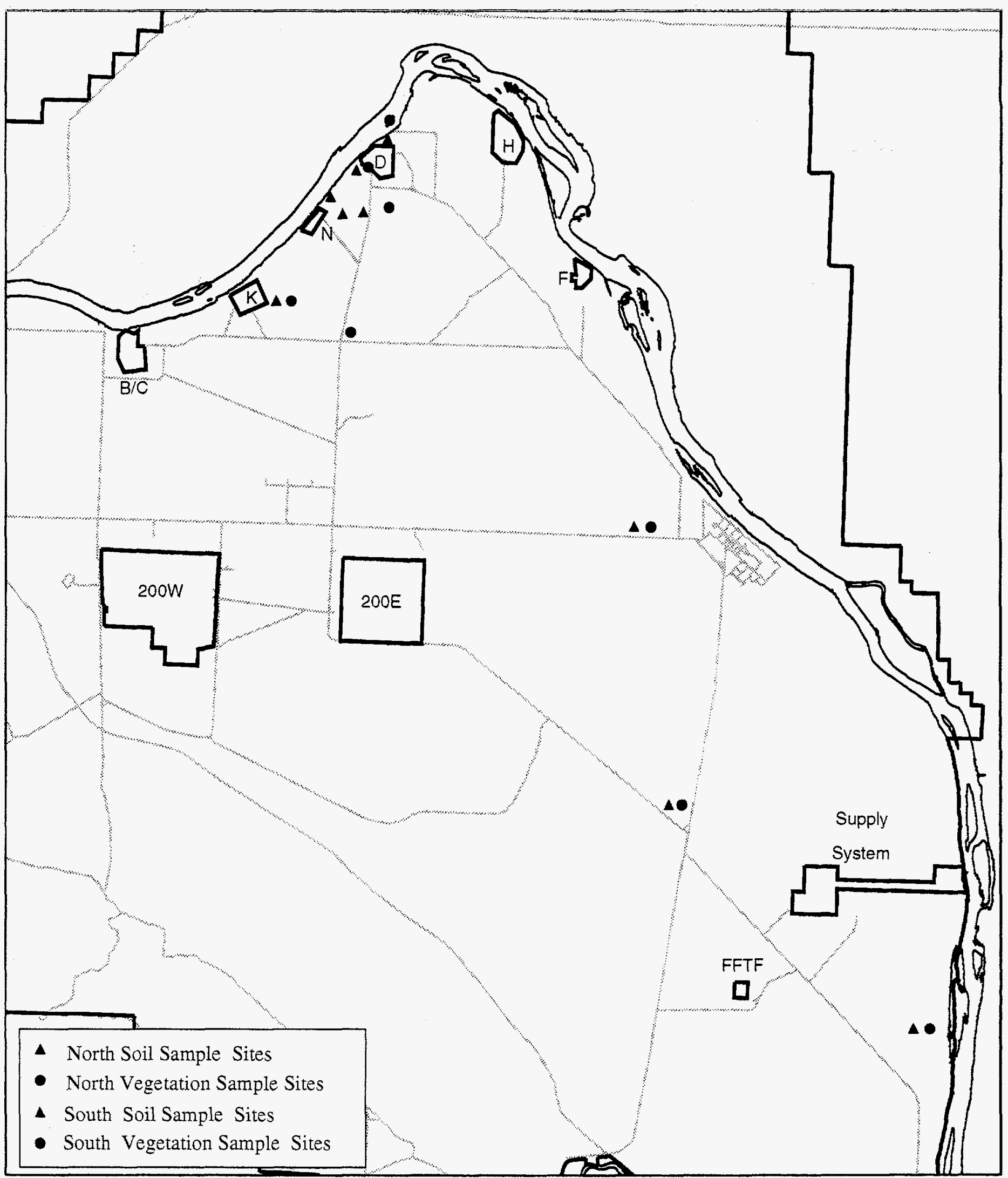

Figure 3. Soil and Vegetation Sampling Locations included in Hanford Analysis 
Table 1. ANOVA of Log-Transformed Strontium-90 in Selected Soil Samples Corresponding to North and South Deer Home Ranges

\begin{tabular}{|l|c|c|c|c|c|}
\hline & DF & $\begin{array}{c}\text { Sum of } \\
\text { Squares }\end{array}$ & Mean Square & F-Value & P-Value \\
\hline Area & 1 & 0.04614 & 0.04614 & 0.36112 & 0.5507 \\
\hline Residential & 48 & 6.13349 & 0.12778 & & \\
\hline
\end{tabular}

\section{Vegetation Analysis}

The sitewide monitoring database for vegetation samples (annual growth of rabbitbrush and sagebrush) was also evaluated for ${ }^{90} \mathrm{Sr}$ based on the same grouping of north and south areas developed for the deer populations. The data were log normally distributed and, following log-transformation, were analyzed by ANOVA for differences between groups. The ANOVA was insignificant $(\mathrm{P}=$ 0.636 , Table 2) corroborating conclusions of the site soil data analysis that no difference existed in ambient level of ${ }^{90} \mathrm{Sr}$ in the deers' general habitat at Hanford. Vegetation samples were not collected at Silver Lake.

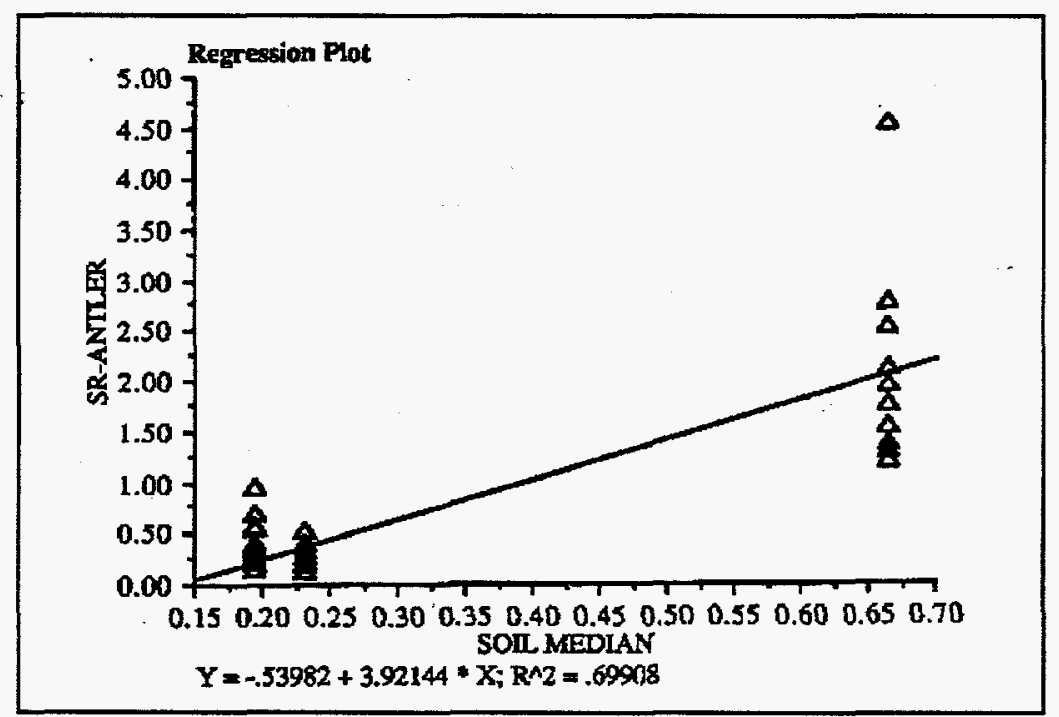

Figure 4. Regression Analysis of Antler Versus Soil Data 
Table 2. ANOVA of Log-Transformed Strontium-90 in Selected Vegetation Samples Corresponding to North and South Deer Home Ranges

\begin{tabular}{|l|c|c|c|c|c||}
\hline & DF & $\begin{array}{c}\text { Sum of } \\
\text { Squares }\end{array}$ & Mean Square & F-Value & P-Value \\
\hline Group & 1 & 0.062 & 0.062 & 0.22639 & 0.6364 \\
\hline Residential & 48 & 14.63384 & 0.30487 & & \\
\hline
\end{tabular}

Shoreline vegetation found along the 100-N Area from 1990 through 1992 had an elevated concentration of ${ }^{90} \mathrm{Sr}$ compared to other shoreline areas in the Hanford Reach (Antonio et al. 1993). Mulberry (Morus alba) leaves were found to contain the highest concentrations $[440( \pm 80) \mathrm{pCi} / \mathrm{g}]$, compared to yarrow (Achillea millefolium), chickory (Cichorium intybus), and willow (Salix spp.). Very little foraging data are currently available for deer residing along the Columbia River; however, field observations of deer eating mulberry and willow are common during the summer months. Shoreline vegetation from the 100-N Area represents one potential source of contamination that may explain the apparent elevated concentration of ${ }^{90} \mathrm{Sr}$ found in antlers from the north population. If this were the major ${ }^{90} \mathrm{Sr}$ source for deer uptake, continued monitoring of deer antlers should show a decrease in antler ${ }^{90} \mathrm{Sr}$ concentrations now that the contaminated vegetation from the $100-\mathrm{N}$ shoreline has been removed.

\section{Animal Movements}

Home range areas and subpopulation intermixing were examined to further evaluate the observed differences in ${ }^{90} \mathrm{Sr}$ concentrations between the 100 areas and old Hanford Townsite/dunes areas. A potential source of error was introduced when grouping the antler data by location since areas of use were not determined for all animals included in this study. This error could have occurred by capturing an animal that resides in one location but, because of capture activity, had moved a considerable distance from its usual home range. To examine this possibility, animal capture sites and relocations of all deer tagged with radio transmitters in 1991 and 1992 were plotted on the GRASS Geographical Information System (GIS) and color coded by capture site (Figure 5).

Animals caught at or below the Hanford Townsite ranged down river extensively but were rarely present at any distance up river from this location (Figure 5). Animals captured upriver from the Hanford Townsite were never found downstream of this site. It appears that animals captured near $100-\mathrm{F}$ do not readily move upstream to the other reactor sites; however, those animals residing around $100-\mathrm{BC}, 100-\mathrm{K}, 100-\mathrm{N}, 100-\mathrm{D}$, and $100-\mathrm{H}$ readily intermix and use that entire portion of land. Figure 6 identifies location data for 17 bucks on the Hanford Site that were captured, sampled, and equipped with radio transmitters in 1992, 1993, and 1994. One animal captured near 100-F in 1992 was recaptured in 1994 near 100-H and sampled again (see raw data Appendix A).

Fourteen animals (eight bucks from which antlers were collected and six does) were used to examine deer home-range areas. Six does were also included for area-use indicators of each group because extensive monitoring data for them was available. From 1992 to 1994, 566 relocations of 


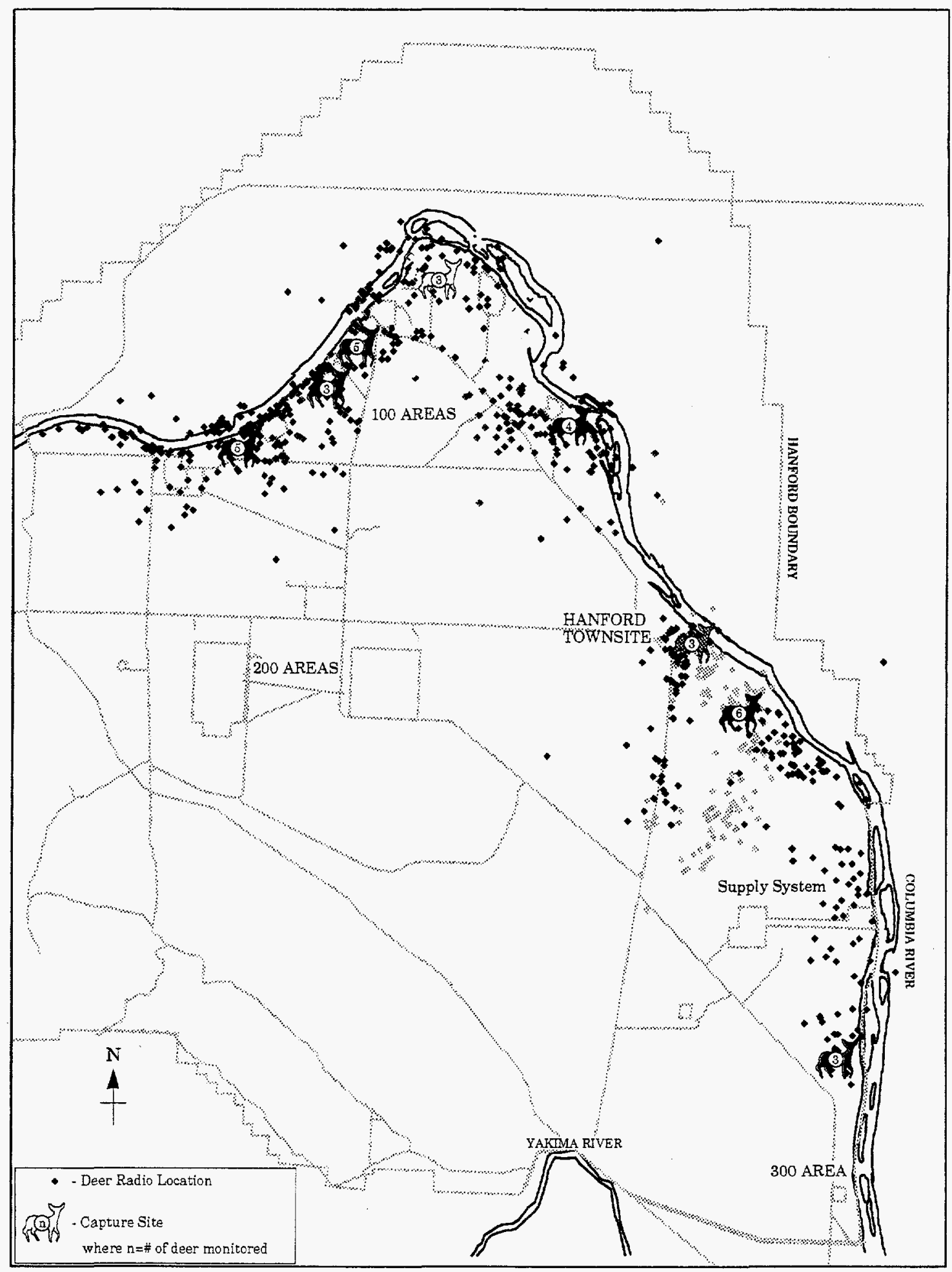

Figure 5. Deer Locations Relative to Capture Sites 1991 - 1992. Illustrates intermixing of deer captured at several sites along river. Color of deer symbol corresponds to color of location points. 


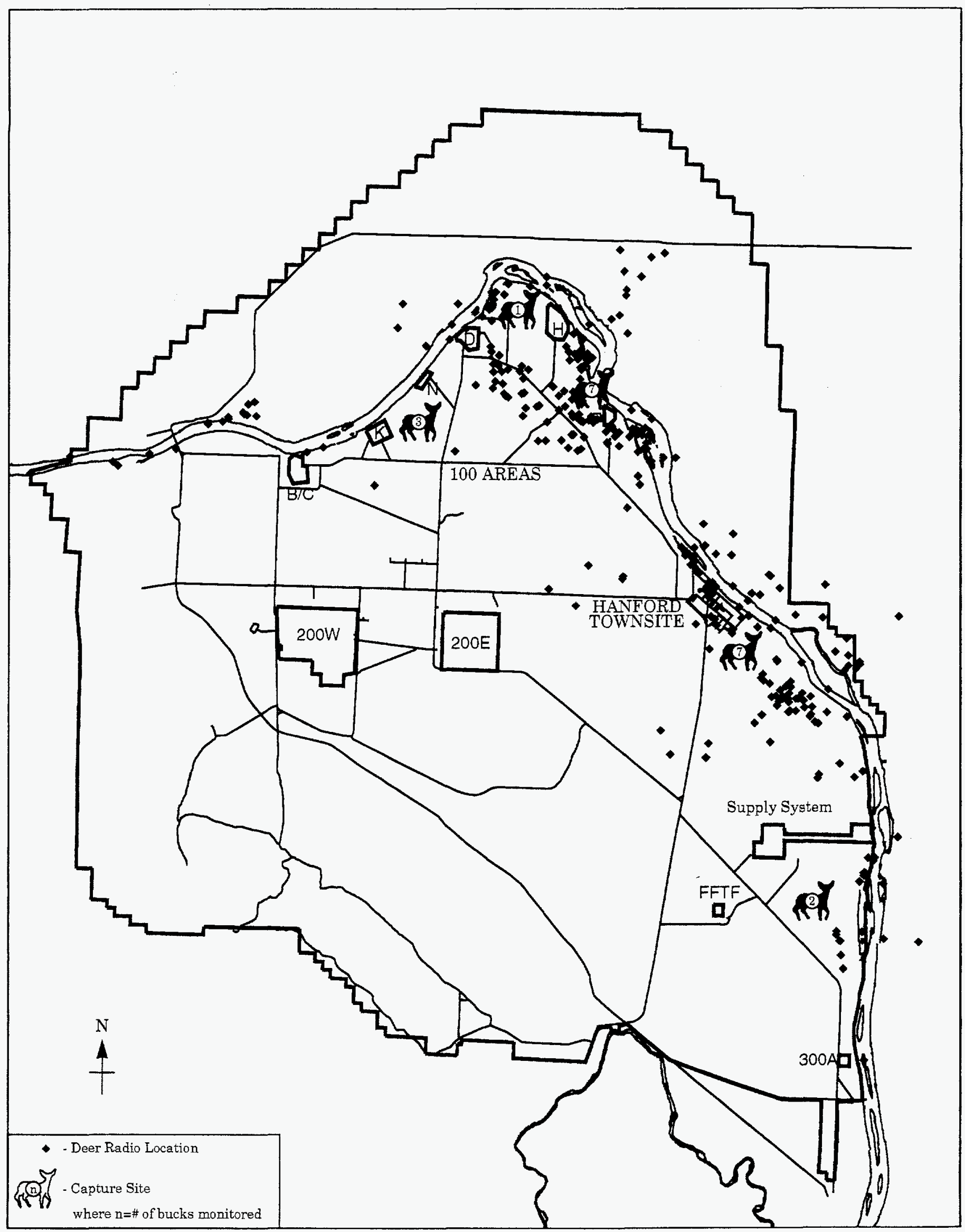

Figure 6. Plotted Re-locations of Bucks Sampled for Strontium-90. Examines potential error of collecting antlers from one capture region where animals may not normally occur. 
these deer were made with an average of $40 \pm 16$ (1 standard deviation) relocations per animal and were tracked an average of $17 \pm 6$ (1 standard deviation) months. Total monitoring time represents 20 deer years with tracking time slightly emphasized through the summer months when antlers are developing.

Depending on the biological question being asked, various home range estimate techniques are more suitable than others. In this study, the size of the home range was not as important as the extent of area used by individual deer within the two sub-populations. Most radio equipped animals did not use their home range in a uniform pattern. The distribution of movements for animals with an adequate number of relocations was examined to help choose a suitable home-range estimator. Animal location distributions were tested for bivariate normality, weighted bivariate normality, and bivariate uniformity using Cramer von-Miss goodness of fit (Appendix B). Although bivariate normality appeared to fit the movement distribution of more animals than did the other two distributions, the majority of animals (eight out of 14) did not fit any underlying distribution. For this reason coupled with a relatively variable number of relocations for the study animals, the nonparametric $95 \%$ harmonic mean technique was chosen for estimating the extent and size of home ranges. Furthermore, home range area estimates for the $95 \%$ harmonic mean technique were larger than $100 \%$ and $95 \%$ minimum convex polygon technique (Appendix B). The $95 \%$ harmonic mean estimate is therefore a more conservative evaluation of animal group intermixing potential.

Based on the $95 \%$ harmonic mean home-range estimate technique (Appendix B), average home range size was $24.7 \pm 12.5 \mathrm{Km}^{2}$ (1 standard deviation) and ranged from $12.3 \mathrm{~km}^{2}$ to $52.1 \mathrm{~km}^{2}$. Figure 7 illustrates the estimated home ranges of these 14 deer. There appeared to be no significant $(P$ $>0.1)$ difference in home-range size between does and bucks. These results are consistent with findings by Eberhardt et al. (1982) who reported an average home-range size of 37 deer to be $39 \pm$ $27 \mathrm{~km}^{2}$ (1 standard deviation) using the elliptical technique. To further illustrate animal movements observed within the north and south areas, this figure includes over 1300 relocation points from 32 does residing within the two sub-populations monitored from 1991 to 1993.

Although the mean home range estimates reported in our study are smaller than those reported by Eberhardt et al. (1982), the associated variation is such that they are not significantly different. Differences might be expected because our study focused on populations residing along the river, and 20 of the 37 deer tracked by Eberhardt et al. 1982 occupied the 200 areas. Factors that influence home range include availability of water and trees. At the time of the Eberhardt study, the 200 Area had two major sources of water for deer in B Pond and Gable Mountain pond (West Lake is too saline for a viable drinking water source for wildlife [Poston et al. 1991; Poston and Cooper 1994]). Essentially, no tree grew around the 200 Area except a few willows, poplars, or cottonwoods around the aquatic waste sites (Emery and McShane 1978) and some small fruit or ornamental trees planted by military personnel in areas once used as military camps. In contrast, the riparian zone along the Columbia River contains numerous trees, and the abandoned agricultural areas associated with White Bluffs and the Hanford Townsite have numerous shade or orchard trees. Therefore, because water and shade trees along the Columbia River were not as limiting as the 200 Areas, home ranges may be reduced. 


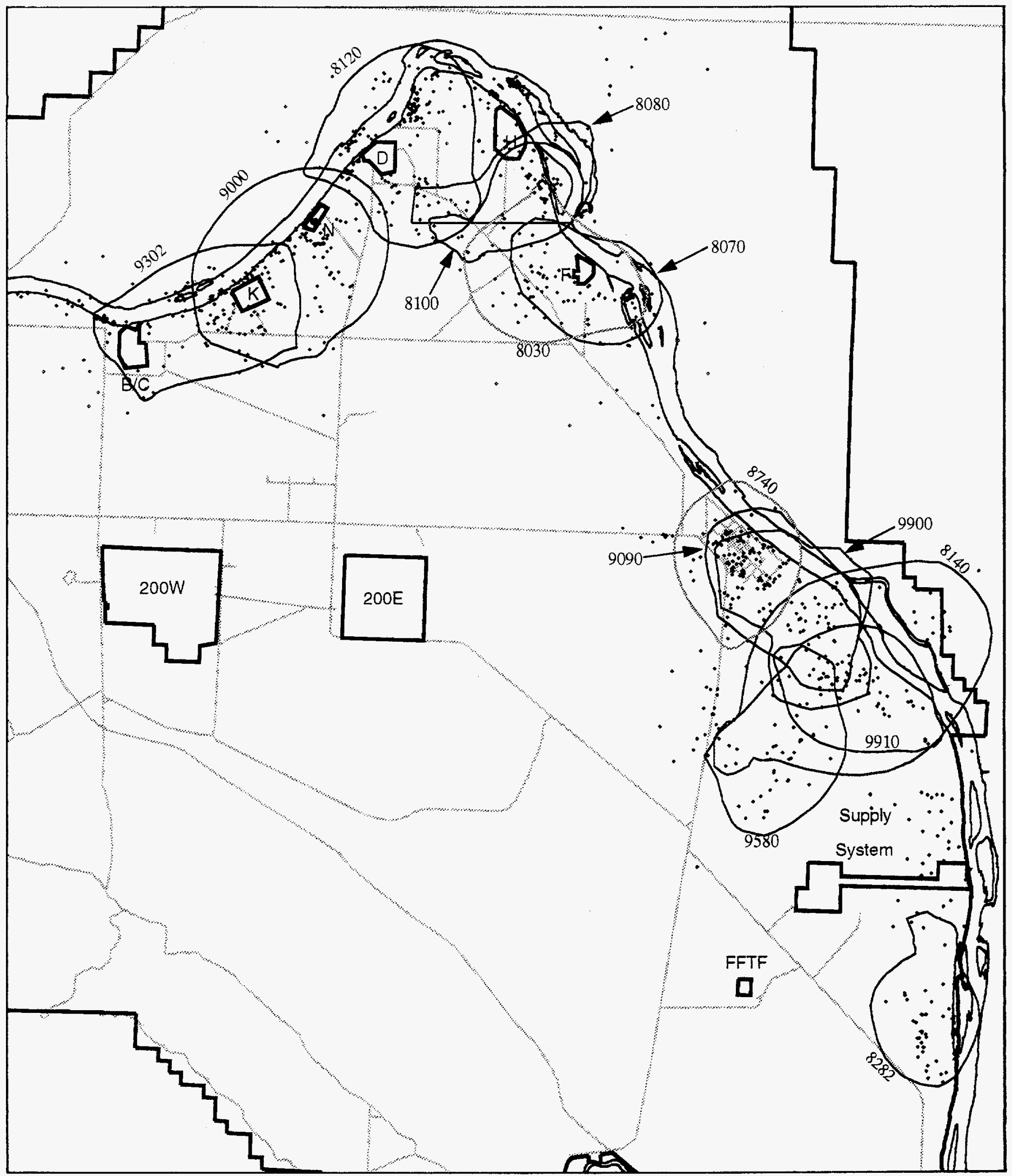

Figure 7. Home Ranges of Selected Bucks and Does on Hanford 


\section{Offsite Movements and Harvest Potential}

Although lands within the Hanford Site boundaries are closed to public hunting, animals residing on Hanford have the potential to move offsite and be harvested, especially those animals residing near the Hanford boundaries. By tagging several deer with radio transmitters and routinely relocating these animals, the extent and frequency of deer movements to islands on the Columbia River and areas across the river could be determined, including movements to the Wahluke Slope Wildlife Recreation Area and private property where the animals are available to legal hunting.

Based on a previous tagging study of fawn deer along the Columbia River and tagging adult deer with radio transmitters in the 200 Areas, it is known that some Hanford Site resident deer move offsite and are harvested by hunters (Eberhardt et al. 1979, 1982). Fawn movements of up to $113 \mathrm{~km}$ have been documented. Until this study, however, it has not been possible to quantify potential of offsite movements: An objective of this study was to collect data necessary to evaluate the frequency and extent of offsite movements by adult deer residing on Hanford near the Columbia River.

A total of 1,423 animal locations from 53 deer (15 bucks and 38 does) tagged with radio transmitters were used to evaluate the potential and extent of offsite movements by adult deer residing along the Hanford Reach. Frequent movements across the river or onto riverine islands were made by several radio monitored deer, particularly during the breeding and fawning seasons (October-December and May-July).

Twenty-four ( $45 \%$ ) of the 53 animals tagged with radio transmitters were located at least once either across the river or on the islands during this study. For those animals that were known to have crossed the river during our study, 125 of 954 (13\%) of the relocations occurred either on the islands or across the Columbia River from Hanford proper. This suggests that adult deer are not bound by the river shores and they will readily swim the river in search of food, cover, and breeding mates. Of the 125 relocations that occurred either on the islands or across the Columbia River from the Hanford Site, only 23 of them (18\%) were found to be on legally huntable lands.

The extent of offsite movement by deer tagged with radio transmitters, in general, has been small as the most frequently visited locations occur immediately adjacent to Hanford along the riparian edge of the Columbia River. About $75 \%$ of deer relocations where found within $500 \mathrm{~m}$ of the Columbia River shoreline (Table 3). The reader should note, however, that land below the river high water mark was not considered offsite (the accuracy of location data does not make it possible to consider). This land is owned and controlled by the Corps of Engineers and is potentially huntable.

Deer hunting is common on lands adjacent to the Hanford Site, and in particular, on the back side of Rattlesnake Mountain. Until now, however, little information has been available regarding the hunting pressure on riverine islands and along the shorelines of the Hanford Reach. In 1994, 20 male deer residing near the Columbia River were captured, radio tagged, and released for future monitoring purposes. One animal lost its radio transmitter within the first month after the capture but the remaining deer were systematically tracked by air and observed on the ground through the 1994 hunting season. A total of four (21\%) of the males were harvested during the 1994 hunting season, three $(16 \%)$ of those animals were legally harvested and one $(5 \%)$ was illegally harvested on the Saddle Mountain Wildlife Refuge near state highway 24. Based on data gathered from 1991 to 1994, an 
Table 3. Distribution of Locations from the Columbia River

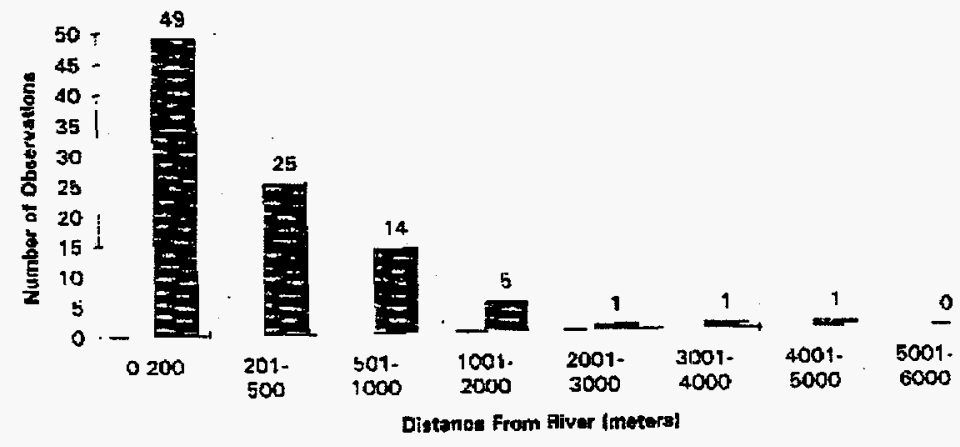

average of $11 \%$ (range $0 \%$ to $37 \%$ at the $95 \%$ confidence interval) of the male deer residing along the Columbia River may be harvested in any one year. A lower average harvest rate (legal or illegal) of female deer was determined to be $5 \%$ (range $0 \%$ to $21 \%$ at the $95 \%$ confidence level). The female deer harvest results in this study are consistent with Eberhardt et al. 1982 as they estimated the probability of a female deer being legally or illegally harvested during any given year at $8 \%$ (range 0 to $21 \%$ at the $95 \%$ confidence interval). A population estimate is needed to determine the actual number of deer harvested in any one year.

\section{Conclusions}

Monitoring contaminants in mobile animals can often display high variability of results and make data interpretations difficult. In this study, variability was reduced when data were grouped by general locations, i.e., North Area (old reactor sites) versus South Area (old Hanford Townsite/Dunes Area). Monitoring subsequent movements of several sampled animals residing within these two regions strongly supported observed differences in levels of ${ }^{90} \mathrm{Sr}$ found in antlers. Considering the approximate 20 deer-years worth of movement data that was attained in this study, it can be concluded with relative confidence that the concentration of ${ }^{90} \mathrm{Sr}$ found in antlers is indicative of elevated environmental exposure in areas defined by the home ranges of these study animals.

Concentrations of ${ }^{90} \mathrm{Sr}$ measured in deer antlers are low and do not indicate excessive exposure to the radionuclide in the environment. On the Hanford Site, antlers collected from the northern population had significantly higher levels of ${ }^{90} \mathrm{Sr}$ than antlers collected from the southern population. However, levels of ${ }^{90} \mathrm{Sr}$ in Hanford deer were much lower than deer antlers collected from a reference location near Silver Lake, Oregon.

Analysis of the soil samples from the mountainous home-range region of Silver Lake deer indicated higher environmental concentrations of ${ }^{90} \mathrm{Sr}$ than what was found in the shrub-steppe area at Hanford. Monitoring data of soil and terrestrial vegetation (sagebrush and rabbitbrush) indicated no differences 
in environmental concentrations of ${ }^{90} \mathrm{Sr}$ between the north and south area data. Studies of riparian vegetation from 1990 through 1992 did indicate that vegetation growing in the $\mathrm{N}$-springs area had elevated concentrations of ${ }^{90} \mathrm{Sr}$. Other unknown sources of exposure could exist.

Monitoring resident deer movement suggest that the river is not a real boundary for them. Although offsite movements were minimal compared to all movements observed, a relatively high proportion of male deer were harvested in $1994(21 \%)$. Female deer were harvested at a much lower rate than the male deer. While ${ }^{90} \mathrm{Sr}$ in antler may not be directly consumed by hunters, it does provide an indication that animals may have been exposed to contamination and perhaps other radionuclides like ${ }^{60} \mathrm{Co}$ or ${ }^{137} \mathrm{Cs}$ may be present in tissues that could be consumed. 


\section{References}

Ackerman, B. B., F. A. Leban, M. D. Samuel, and E. O. Garton. 1990. User's Manual for Program Home Range. Second Edition. Technical Report 15, Forestry, Wildlife and Range Experiment Station, University of Idaho, Moscow, Idaho.

Antonio, E. J., T. M. Poston, and W. H. Rickard, Jr. 1993. Radiological Survey of Shoreline Vegetation from the Hanford Reach of the Columbia River, 1990 - 1992. PNL-8797, Pacific Northwest Laboratory, Richland, Washington.

Beasom , S. L., W. Evans, and L Temple. 1980. "The Drive Net for Capturing Western Big Game." J. Wildl. Manage. 44(2):478-483.

Bekoff, M., and L. D. Mech. 1984. Simulation Analyses of Space Use: Home Range Estimates, Variability, and Sample Size. Behavior Research Methods, Instruments and Computers 16(1):32-37.

Bowen, W. D. 1982. "Home Range and Spatial Organization of Coyotes in Jasper National Park, Alberta." J. Wildl. Manage. 46(1):201-216.

Chatters, J. C., 1989. "Hanford Cultural Resources Management Plan" PNL-6942, Pacific Northwest Laboratory, Richland, Washington.

Daubenmire, R. 1970. Steppe Vegetation of Washington. Tech. Bull. 62. Washington Agricultural Experimental Station, Washington State University, Pullman, Washington.

Digregorio, D., T. Kitching, and P. Van Voris. 1977. "Radionuclide Transfer in Terrestrial Animals." Health Phys. 34:3-31.

Dixon, K. R., and J. A. Chapman. 1980. "Harmonic Mean Measure of Animal Activity Areas." Ecology 61(5):1040-1044.

Downs, J. L., W. H. Rickard, C. A. Brandt, L. L. Cadwell, C. E. Cushing, D. R. Geist, R. M. Mazaika, D. A. Neitzel, L. E. Rogers, M. R. Sackschewsky, and J. J. Nugent. 1993. Habitat Types on the Hanford Site: Wildlife and Plant Species of Concern. PNL-8942, Pacific Northwest Laboratory, Richland, Washington.

Eberhardt, L. E., E. E. Hanson, and L. L. Cadwell. 1982. Analysis of Radionuclide Concentrations and Movement Patterns of Hanford Site Mule Deer. PNL-4420, Pacific Northwest Laboratory, Richland, Washington.

Eberhardt, L. E., and L. L. Cadwell. 1983. "Radio-Telemetry as an Aid to Environmental Contaminate Evaluation of Mobile Wildlife Species." Environ. Mon. Assess. (5):283-289.

Emery, R. M., and M. C. McShane. 1978. Comparative Ecology of Nuclear Waste Ponds and Streams on the Hanford Site. PNL-2499. Pacific Northwest Laboratory, Richland, Washington. 
Erickson, J. A. and W. G. Seliger. 1969. "Efficient Sectioning of Incisors for Establishing Ages of Mule Deer." J. Wildl. Manage. 33:384-388.

Farris G. C., F. W. Whicker, and A. H. Dahl. 1967. "Effect of Age on Radioactive and Stable Strontium Accumulation in Mule Deer Bone." In Strontium Metabloism, J.M. A. Lenihan, J. F. Loutit and J. H. Martin, eds., pp. 93-102. Academic Press, London.

Hoitink, D. J., and K. W. Burk. 1994. Climatological Data Summary 1993 with Historical Data. PNL-9809, Pacific Northwest Laboratory, Richland, Washington.

Low, W. A. and I.McT. Cowan. 1963. "Age Determination of Deer by Ammula Structure of Dental Cementum." J. Wildl. Manage. 27:466-471.

MacLellan, J. A., T. P. Lynch, G. A. Rieksts, and R. L. Brodzinski. 1993. "Identification of Environmentally Derived Cesium-137 Burdens in a Worker Population". In Environmental Health Physics, Proceedings of the 26th Year Topical Meeting of the Health Physics Society, R. L. Kathern., D. H. Denham, K. Salmon, and D. Felton, eds., pp. 171-179. January 24-28, 1993, Coeur d'Alene, Idaho. Research Enterprises, Inc.. Richland, Washington. pp. 171-179.

Michener, G. R. 1979. "Spatial Relationships and Social Organization of Adult Richardson's Ground Squirrels." Can. J. Zool. 57(1):125-129.

Mielke, P. W. 1991. "The Application of Multivariate Permutation Methods Based on Distance functions in the Earth Sciences." Earth-Science-Reviews. 31(1):55-71

National Council on Radiation Protection and Measurements (NCRP). 1991. Some Aspects of Strontium Radiobiology, NCRP Report No 110, NCRP, Washington, D.C.

Osburn, W. S., 1967. Ecological concentration of nuclear fallout in a Colorado mountain watershed. In Radioecological Concentration Processes (B. Aberg and F. P. Hungate, Eds.) pp. 675709. Pergamon, New York.

Poston, T. M., K. R. Price, and D. R. Newcomer. 1991. An Evaluation of the Chemical, Radiological, and Ecological Conditions of West Lake on the Hanford Site. PNL-7662. Pacific Northwest Laboratory, Richland, Washington.

Poston, T. M., and A. T. Cooper. 1994. A Qualitative Evaluation of Radionuclide Concentrations in Hanford Site Wildlife, 1983 through 1992. PNL-10174. Pacific Northwest Laboratory, Richland, Washington.

Price, K. R., L. L. Cadwell, R. G. Schreckhise, and F. P. Brauer. 1981. Iodine-129 in Forage and Deer on the Hanford Site and Other Pacific Northwest Locations. PNL-3357, Pacific Northwest Laboratory, Richland, Washington.

Robinette, W. L., D. A. Jones, G. Rogers, and J. S. Gashwiler. 1957. "Notes on tooth development and wear for Rocky Mountain mule deer." J. Wildl. Manage. 21:134-153. 
Sackschewsky, M. R., D. S. Landeen, J. L. Downs, W. H. Rickard, G. I Baird. 1992. Vascular Plants of the Hanford Site. WHC-EP-0554, Westinghouse Hanford Company, Richland, Washington.

Samuel, M. D., and E. O. Garton. 1985. "Home Range: A Weighted Normal Estimate and Tests of Underlying Assumptions." J. Wildl. Manage. 49(2):513-519.

Schreckhise, R. G. 1974. Strontium Kinetics in Mule Deer. Ph.D. Dissertation. Colorado State University. Fort Collins, Colorado.

Schultz, V. 1964. "Sampling White-Tailed Deer Antlers for Strontium-90." J. Wildl. Manage. 28(1):43-49.

Soldat, J. K., K. R. Price, and W. H. Rickard. 1990. Methodology Used to Compute Maximum Potential Doses from Ingestion of Edible Plants and Wildlife Found on the Hanford Site. PNL-7539, Pacific Northwest Laboratory, Richland, Washington.

Wallmo, O. C. 1981. Mule and Black-Tailed Deer of North America. A Wildlife Management Institute Book. University of Nebraska Press, Lincoln, Nebraska.

Water Information Center, Inc. (WIC). 1974. Climates of the United States, Vol. II - Western States. Water Information Center, Inc. Port Washington, New York.

Whicker, R. W., B. C. Farris, E. E. Remmenga, and A. H. Dahl. 1965. "Factors Influencing the Accumulation of Fallout ${ }^{137} \mathrm{Cs}$ in Colorado Mule Deer." Health Physics. 11:1407-1414

Woodruff, R. K., and R. W. Hanf (eds.). 1992. Hanford Site Environmental Report for Calendar Year 1991. PNL-8148, Pacific Northwest Laboratory, Richland, Washington.

Zaleha, M. J. , and J. Kovach. 1985. "Strontium Concentrations in Deer Antlers from Eastern Ohio, Western Pennsyvania, and Northern West Virginia." In Ohio Journal of Science, 94th Annual Meeting. April Program Abstracts No. 2. 


\section{Appendix A}




\section{Sr-90 CONCENTRATIONS IN ANTLERS}

\begin{tabular}{|c|c|c|c|c|c|}
\hline Group & Location & Concentration & Date & Animal ID & Age \\
\hline 100Area & $100-\mathrm{F}$ & 0.574 & $2 / 18 / 94$ & 8.470 & 2 \\
\hline 100Area & $100-\mathrm{F}$ & 0.505 & $2 / 18 / 94$ & 8.310 & 2 \\
\hline 100Area & $100-\mathrm{F}$ & 0.125 & $2 / 18 / 94$ & 8.080 & 8 \\
\hline 100Area & $100-\mathrm{F}$ & 0.309 & $2 / 5 / 92$ & 8.070 & \\
\hline 100Area & $100-\mathrm{F}$ & 0.348 & $2 / 5 / 92$ & 8.710 & \\
\hline 100Area & $100-F$ & 0.541 & $2 / 5 / 92$ & 8.030 & $\therefore$ \\
\hline 100Area & $100-\mathrm{H}$ & 0.277 & $2 / 18 / 94$ & 8.710 & 5 \\
\hline 100Area & 100-D & 0.348 & $2 / 5 / 92$ & 8.120 & \\
\hline 100Area & $100-K$ & 0.932 & $2 / 19 / 94$ & 8.490 & 1 \\
\hline 100Area & $100-K$ & 0.151 & $2 / 19 / 94$ & 8.980 & 12 \\
\hline 100Area & $100-K$ & 0.208 & $2 / 19 / 94$ & 8.250 & 10 \\
\hline 100Area & $100-K$ & 0.334 & $2 / 5 / 92$ & & \\
\hline 100Area & $100-K$ & 0.387 & $2 / 15 / 91$ & & \\
\hline 100Area & $100-K$ & 0.677 & $2 / 15 / 91$ & & \\
\hline HTS/DUNE & H.T.S./Dune & 0.118 & $2 / 14 / 91$ & & \\
\hline HTS/DUNE & H.T.S./Dune & 0.190 & $2 / 14 / 91$ & & \\
\hline HTS/DUNE & H.T.S./Dune & 0.243 & $2 / 14 / 91$ & & \\
\hline HTS/DUNE & H.T.S./Dune & 0.0989 & $2 / 14 / 91$ & & \\
\hline HTS/DUNE & H.T.S./Dune & 0.160 & $2 / 14 / 91$ & & \\
\hline HTS/DUNE & H.T.S./Dune & 0.132 & $2 / 18 / 94$ & 8.430 & 3 \\
\hline HTS/DUNE & H.T.S./Dune & 0.255 & $3 / 21 / 93$ & 9.932 & 8 \\
\hline HTS/DUNE & H.T.S./Dune & 0.383 & $2 / 17 / 94$ & 8.580 & 2 \\
\hline HTS/DUNE & H.T.S./Dune & 0.168 & $2 / 17 / 94$ & 8.820 & 2 \\
\hline HTS/DUNE & H.T.S./Dune & 0.233 & $2 / 17 / 94$ & 8.910 & 2 \\
\hline HTS/DUNE & H.T.S./Dune & 0.239 & $2 / 17 / 94$ & 9.920 & 2 \\
\hline HTS/DUNE & H.T.S./Dune & 0.234 & $2 / 17 / 94$ & 8.970 & 3 \\
\hline HTS/DUNE & H.T.S/Dune & 0.159 & $2 / 18 / 94$ & 8.130 & 2 \\
\hline HTS/DUNE & H.T.S./Dune & 0.103 & $2 / 17 / 94$ & 8.990 & 2 \\
\hline$S L, O R$ & Silver Lake, OR & 2.09 & $4 / 1 / 91$ & & \\
\hline$S L, O R$ & Silver Lake, OR & 1.35 & $4 / 1 / 92$ & & \\
\hline$S L, O R$ & Silver Lake, OR & 1.51 & $4 / 1 / 92$ & & \\
\hline$S L, O R$ & Silver Lake, OR & 1.74 & $4 / 1 / 93$ & & \\
\hline$S L, O R$ & Silver Lake, OR & 1.28 & $4 / 1 / 93$ & & \\
\hline$S L, O R$ & Silver Lake, OR & 1.19 & $4 / 1 / 93$ & & \\
\hline$S L, O R$ & Silver Lake, OR & 1.94 & $4 / 1 / 94$ & & \\
\hline SL, OR & Silver Lake, OR & 2.51 & $4 / 1 / 94$ & & \\
\hline$S L, O R$ & Silver Lake, OR & 4.51 & $4 / 1 / 94$ & & \\
\hline$S L, O R$ & Silver Lake, OR & 2.75 & $4 / 1 / 94$ & & \\
\hline
\end{tabular}


Descriptive Statistics of Sr-90 Results by Location

100-Areas

\begin{tabular}{lr}
\hline \multicolumn{2}{c}{ 100.Areas } \\
\hline Mean & 0.408285714 \\
Standard Error & 0.058732344 \\
Median & 0.348 \\
Mode & 0.348 \\
Standard Deviation & 0.219756309 \\
Variance & 0.048292835 \\
Kurtosis & 1.116538047 \\
Skewness & 1.00578801 \\
Range & 0.807 \\
Minimum & 0.125 \\
Maximum & 0.932 \\
Sum & 5.716 \\
Count & 14
\end{tabular}

\begin{tabular}{|c|c|}
\hline Mean & 0.193993 \\
\hline Standard Error & 0.02057 \\
\hline Mẹedian & 0.179 \\
\hline Mode & $\# N / A$ \\
\hline Standard Deviation & 0.076965 \\
\hline Variance & 0.005924 \\
\hline Kurtosis & 1.413238 \\
\hline Skewness & 0.968713 \\
\hline Range & 0.2841 \\
\hline Minimum & 0.0989 \\
\hline Maximum & 0.383 \\
\hline Sum & 2.7159 \\
\hline Count & 14 \\
\hline
\end{tabular}

Silver Lake, Oregon

$\begin{array}{lr}\text { Mean } & 2.087 \\ \text { Standard Error } & 0.315584 \\ \text { Median } & 1.84 \\ \text { Mode } & \text { \#N/A } \\ \text { Standard Deviation } & 0.997965 \\ \text { Variance } & 0.995934 \\ \text { Kurtosis } & 3.622932 \\ \text { Skewness } & 1.775779 \\ \text { Range } & 3.32 \\ \text { Minimum } & 1.19 \\ \text { Maximum } & 4.51 \\ \text { Sum } & 20.87 \\ \text { Count } & 10\end{array}$


Frequency Distribution of Antler Data
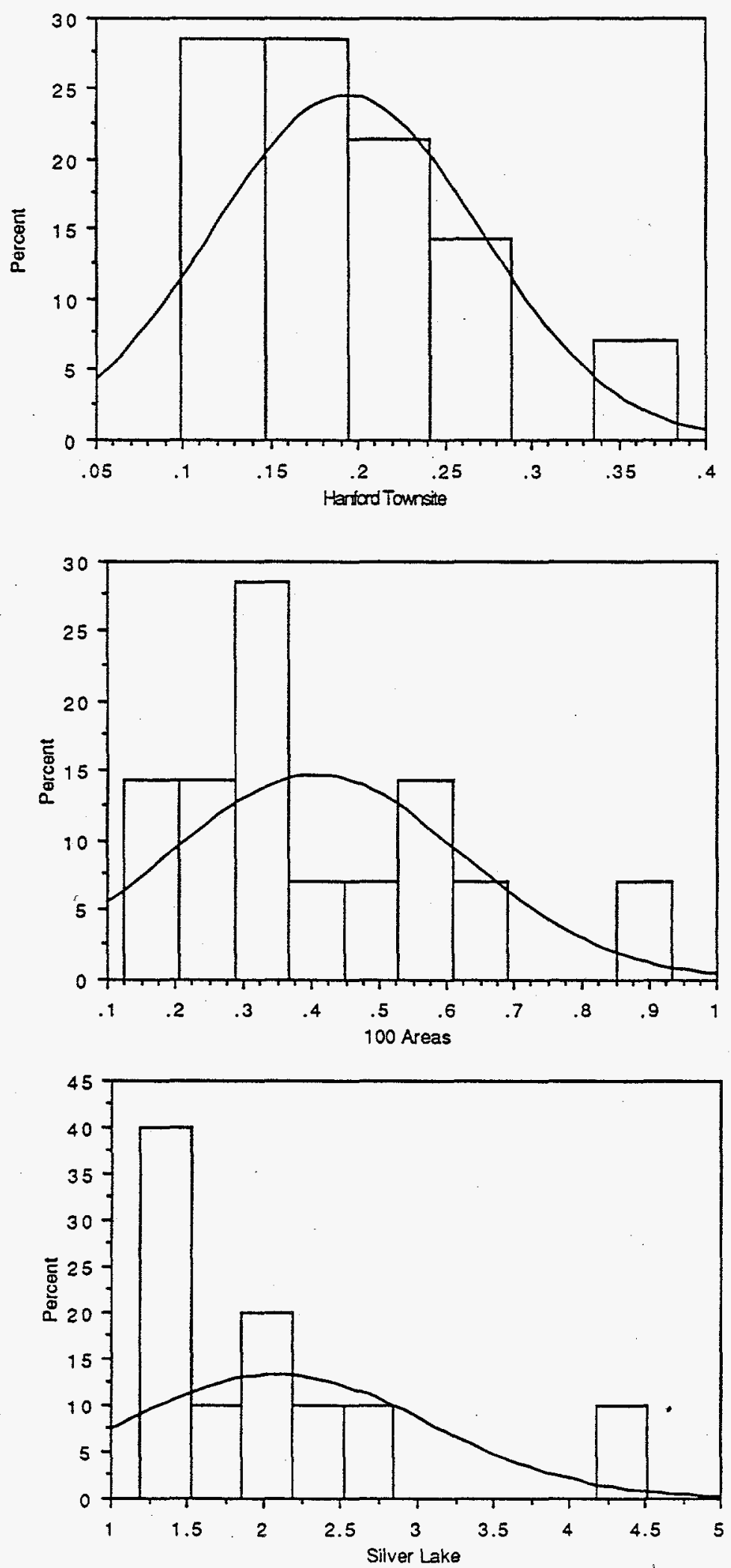

A.3 
$100 \mathrm{BC}$ to $100 \mathrm{~N}$ v.s. $100 \mathrm{D}$ to $100 \mathrm{~F}$ Sr-90 in Antlers

EXACT MULTI-RESPONSE PERMUTATION PROCEDURE RESULTS

NUMBER OF OBJECTS $=14$

NUMBER OF RESPONSES $=1$

DISTANCE EXPONENT $=1.0000000$

NUMBER OF GROUPS $=2$

UPPER DISTANCE BOUND $=100000.00$

$\mathrm{C}(\mathrm{I})=\mathrm{n}(\mathrm{I}) / \operatorname{sum}(\mathrm{n}(\mathrm{I}))$

SIZE OF GROUP $1=6$

SIZE OF GROUP $2=8$

SIZE OF EXCESS GROUP $=0$

1 (0) IMPLIES (NO) C(N,H) RANKS TEST: 0

1 (0) IMPLIES (NO) AVE. DIST. COMMENSURATION: 0

OBSERVED MRPP STATISTIC $=.25496327$

EXACT MRPP P-VALUE $=.63469863$ 
$100 B C$ to $100 \mathrm{~N}$ V.S. $100 \mathrm{D}$ to $100 \mathrm{~F}$ Sr-90 in Antlers

MULTI-RESPONSE PERMUTATION PROCEDURES

INPUT HAS 14 OBSERVATIONS

THERE WERE 1 DIMENSION(S)

IN: 2 GROUPS OF SIZES $8 \quad 6$

$\mathrm{C}(\mathrm{I})=\mathrm{n}(\mathrm{I}) / \operatorname{sum}(\mathrm{n}(\mathrm{I}))$

GROUP NUMBER 1 OF SIZE 8 HAS AN AVERAGE DISTANCE $=\quad .18039286$

GROUP NUMBER 2 OF SIZE 6 HAS AN AVERAGE DISTANCE $=.35766667$

1 (0) IMPLIES (NO) C(N,H) RANKS TEST: 0

1 (0) IMPLIES -(NO) AVE.DIST. COMMENSURATION: 0

THE TEST STATISTIC IS $=.60 .132090$

THE DISTANCE EXPONENT $=1.0000000$

THE UPPER BOUND VALUE $=100000.00$

THE OBSERVED DELTA IS $=.25636735$

THE EXPECTED DELTA IS $=.24789011$

THE VARIANCE OF DELTA $=.19874493 \mathrm{E}-03$

THE SKEWNESS OF DELTA $=-1.9022626$

THE AGREEMENT MEASURE $=-.34197561 \mathrm{E}-01$

P-VALUE OF A SMALLER OR EQUAL DELTA $=.67189934$

*** M R P P EN D 
100 Areas V.S. Hanford Townsite Area Sr-90 in Antlers

MULTI-RESPONSE PERMUTATION PROCEDURES

INPUT HAS 28 OBSERVATIONS

THERE WERE 1 DIMENSION(S)

IN: 2 GROUPS OF SIZES $14 \quad 14$

$\mathrm{C}(\mathrm{I})=\mathrm{n}(\mathrm{I}) / \operatorname{sum}(\mathrm{n}(\mathrm{I}))$

GROUP NUMBER 1 OF SIZE 14 HAS AN AVERAGE DISTANCE $=.24789011$

GROUP NUMBER 2 OF SIZE 14 HAS AN AVERAGE DISTANCE $=$ $.86321978 \mathrm{E}-01$

1 (0) IMPLIES (NO) C(N,H) RANKS TEST: 0

1 (0) IMPLIES (NO) AVE.DIST. COMMENSURATION: 0

THE TEST STATISTIC IS $=-6.4050689$

THE DISTANCE EXPONENT $=1.0000000$

THE UPPER BOUND VALUE $=100000.00$

THE OBSERVED DELTA IS $=.16710604$

THE EXPECTED DELTA IS $=.20434048$

THE VARIANCE OF DELTA $=.33794176 \mathrm{E}-04$

THE SKEWNESS OF DELTA $=-2.1114973$

THE AGREEMENT MEASURE $=.18221761$

P-VALUE OF A SMALLER OR EQUAL DELTA $=.71352658 \mathrm{E}-03$

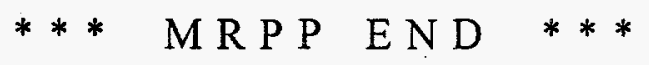




\section{Hanford Site V.S. SilverLake, Oregon Sr-90 in Antlers \\ MULTI-RESPONSE PERMUTATION PROCEDURES}

INPUT HAS 38 OBSERVATIONS

THERE WERE 1 DIMENSION(S)

IN: 2 GROUPS OF SIZES $28 \quad 10$

$\mathrm{C}(\mathrm{I})=\mathrm{n}(\mathrm{I}) / \operatorname{sum}(\mathrm{n}(\mathrm{I}))$

GROUP NUMBER 1 OF SIZE 28 HAS AN AVERAGE DISTANCE $=.20434048$

GROUP NUMBER 2 OF SIZE 10 HAS AN AVERAGE DISTANCE $=1.0646667$

1 (0) IMPLIES (NO) C(N,H) RANKS TEST: 0

1 (0) IMPLIES (NO) AVE.DIST. COMMENSURATION: 0

THE TEST STATISTIC IS $=-22.369215$

THE DISTANCE EXPONENT $=1.0000000$

THE UPPER BOUND VALUE $=100000.00$

THE OBSERVED DELTA IS $=\cdot .43074211$

THE EXPECTED DELTA IS $=.88931963$

THE VARIANCE OF DELTA $=.42026580 \mathrm{E}-03$

THE SKEWNESS OF DELTA $=-2.3056067$

THE AGREEMENT MEASURE $=.51564984$

P-VALUE OF A SMALLER OR EQUAL DELTA $=.67739477 \mathrm{E}-09$

MRP P E N D *** 
Appendix B 
Table B.1. Cramer-von Mises Goodness of Fit Distribution

\begin{tabular}{|c|c|c|c|c|}
\hline & & \multicolumn{3}{|c|}{ Distribution } \\
\hline \multicolumn{2}{|c|}{ Goodness of Fit Results } & $\begin{array}{l}\text { Bivariate } \\
\text { Uniform }\end{array}$ & $\begin{array}{c}\text { Bivariate } \\
\text { Normal }\end{array}$ & $\begin{array}{c}\text { Weighted } \\
\text { Bivariate } \\
\text { Normal }\end{array}$ \\
\hline \multirow{2}{*}{\multicolumn{2}{|c|}{$\begin{array}{l}P>0.10 \text { (Fit) } \\
P<0.10 \text { (Does Not Fit) }\end{array}$}} & 4 & 6 & 4 \\
\hline & & 10 & 8 & 10 \\
\hline \multicolumn{2}{|c|}{ Animal ID } & & & \\
\hline 8030 & Male & $P<.01$ & $P<.05$ & $\mathrm{P}<.025$ \\
\hline 8080 & Male & $P>.15$ & $.1<P<.15$ & $.05<P<.1$ \\
\hline 8100 & Male & $.025<P<.05$ & $P<.01$ & $.025<P<.05$ \\
\hline 8120 & Male & $P>.15$ & $.1<P<.15$ & $.1<P<.15$ \\
\hline 8070 & Male & $P>.15$ & $.05<P<.1$ & $P<.01$ \\
\hline 8282 & Female & $P>.15$ & $P>.15$ & $.1<P<.15$ \\
\hline 9900 & Male & $.05<P<.1$ & $P<.01$ & $P<.01$ \\
\hline 8140 & Male & $P<.01$ & $P>.15$ & $.05<P<.1$ \\
\hline 9910 & Male & $P<.01$ & $.1<P<.15$ & $.05<P<.1$ \\
\hline 9000 & Female & $p<.01$ & $P<.01$ & $P<.01$ \\
\hline 9090 & Female & $P<.01$ & $.025<P<.05$ & $.025<P<.01$ \\
\hline 9580 & Female & $P<.01$ & $01<\mathrm{P}<.025$ & $.05<P<.1$ \\
\hline 9302 & Female & $P<.01$ & $.05<P<.1$ & $01<\mathrm{P}<.025$ \\
\hline 8740 & Female & $.025<P<.05$ & $.1<P<.15$ & $.1<P<.15$ \\
\hline
\end{tabular}

B. 1 
Table B.2. Comparison of Home Range Estimates

\begin{tabular}{|c|c|c|c|c|c|c|c|c|}
\hline \multirow[b]{3}{*}{$\begin{array}{l}\text { General } \\
\text { Location }\end{array}$} & \multirow[b]{3}{*}{ Deer \# } & \multirow[b]{3}{*}{$\begin{array}{c}\# \\
\text { Relocations }\end{array}$} & \multirow[b]{3}{*}{ \# Months } & \multirow{2}{*}{\multicolumn{2}{|c|}{$\begin{array}{c}\text { Minimum } \\
\text { Convex Polygon }\end{array}$}} & \multicolumn{2}{|c|}{ Bivariate Ellipse } & \multirow{3}{*}{$\begin{array}{c}\text { Harmonic } \\
\text { Mean } \\
95 \%\end{array}$} \\
\hline & & & & & & \multirow[b]{2}{*}{$\begin{array}{c}\text { Weighted } \\
95 \%\end{array}$} & \multirow[b]{2}{*}{$\begin{array}{c}\text { Normal } \\
95 \%\end{array}$} & \\
\hline & & & & $\begin{array}{l}100 \% \\
\text { MCP }\end{array}$ & $\begin{array}{l}95 \% \\
\text { MCP } \\
\end{array}$ & & & \\
\hline 100-F Area & 8030 & 35 & 15 & 16.7 & 14.6 & 21.4 & 29.7 & 23.3 \\
\hline 100-D Area & 8080 & 46 & 8 & 49.8 & 42.1 & 50.6 & 70.7 & 14.1 \\
\hline 100-D Area & 8100 & 39 & 16 & 15.7 & 7.3 & 43.1 & 26.2 & 12.3 \\
\hline 100-D Area & 8120 & 26 & 12 & 20.9 & 15.3 & 32.4 & 49.6 & 29.5 \\
\hline 100-F Area & 8070 & 21 & 8 & 9.9 & 5.7 & 15.3 & 21.8 & 16.2 \\
\hline 100-N Area & 9000 & 65 & 26 & 23.8 & 18.1 & 21.7 & 29.0 & 38.4 \\
\hline 100-D Area & 9302 & 67 & 26 & 21.0 & 15.2 & 23.0 & 28.1 & 26.7 \\
\hline Old Hanford Townsite & 8282 & 32 & 15 & 10.2 & 9.4 & 14.2 & 18.3 & 15.7 \\
\hline Old Hanford Townsite & 9900 & 26 & 11 & 21.8 & 19.3 & 43.6 & 50.5 & 23.6 \\
\hline Old Hanford Townsite & 8140 & 34 & 18 & 25.0 & 19.4 & 30.3 & 39.6 & 52.1 \\
\hline Old Hanford Townsite & 9910 & 21 & 10 & 7.8 & 5.3 & 12.7 & 16.8 & 19.4 \\
\hline Old Hanford Townsite & 9090 & 64 & 24 & 29.7 & 16.9 & 21.1 & 34.6 & 22.6 \\
\hline Old Hanford Townsite & 9580 & 50 & 22 & 26.6 & 20.6 & 31.9 & 42.5 & 32.9 \\
\hline Old Hanford Townsite & 8740 & 37 & 17 & 7.7 & 5.9 & 8.4 & 12.3 & 18.3 \\
\hline
\end{tabular}




\section{Distribution}

No. of

Copies

Offsite

2 Office of Scientific and

Technical Information

2 Golder Associates

4104 148th Avenue N.E.

Redmond, WA 98052

Attention: L. Swenson

Attention: W. Wright

J. Yokel

Washington Department of Ecology

Mail Stop PV-11

Olympia, WA 98504-8711

2 Environmental Restoration/

Waste Mangement

Yakama Indian Nation

P.O. Box 151

Toppenish, WA 98948

Attention: R. Jim

Attention: M. Bauer

5 Confederated Tribes of the

Umatilla Indian Reservation

P.O. Box 638

Pendleton, OR 97801

Attention: J. Ebaugh

Attention: J. R. Wilkinson

Attention: A. Childs

Attention: R. George

Attention: K. Robson

2 Nez Perce Tribe

P.O. Box 365

Lapwai, ID 83540-0365

Attention: R. Cruz

Attention: D. Powaukee
No. of

Copies

3 Washington State Department of Health

Division of Radiation Protection

Airdustrial Center

Building 5, M.S. C-13

Olympia, WA 98503

Attention: J. Erickson

Attention: L. Albin

Attention: D. Thatcher

Onsite

10 DOE Richland Operations Office

R. F. Brich

J. B. Hall (5)

R. D. Hildebrand

P. S. Kube

D. C. Ward

B. A. Ward

2 U.S. Environmental Protection Agency

L. E. Gadbois

P. S. Innes

7 Westinghouse Hanford Company

L. P. Diediker

J. J. Dorian

E. M. Greager

A. R. Johnson

C. J. Perkins

J. W. Schmidt

Public Reading Room

4 Bechtel Hanford Inc

G. E. Fitzgibbon

K. G. Gano

K. M. Leonard

S. G. Wciss

Distr.1 
No. of

Copies

\section{Pacific Northwest Laboratory}

E. J. Antonio

M. L. Blanton

C. A. Brandt

R. W. Bryce

L. L. Cadwell

A. T. Cooper

D. D. Dauble

R. L. Dirkes

R. M. Ecker

S. L. Friant

J. A. Hall

R. W. Hanf, Jr.
No. of

Copies

R. E. Jaquish (3)

P. R. Nickens

G. W. Patton

T. M. Poston (20)

K. A. Saldi

M. R. Sackschewsky

B. L. Tiller

Publishing Coordination

SESP Historical Filcs/R. L. Dirkes (2)

Technical Report Files (5)

S. A. Rawson

R. L. Skaggs

C. S. Sloane

P. C. Hays - last 